\title{
Taxation and Development. A Capacities Approach
}

\author{
Fernando López Castellano
}

\begin{abstract}
The principal objective of this paper is to show that taxation is a crucial element of good governance and the legitimacy of the State and of the citizen's commitment with politics, and, finally, of development. Assuming that "social heritage" as regards education, health and collective contributions largely explains differences in income at an international level, we investigate the relationships between State and society in terms of taxation and we conclude with the importance of the tax system in the formation of the state and in the adoption of development strategies. In this paper Sen's approach of capacities is adopted, emphasizing the constitutive role of institutions, and it is assumed that the latter must perform the function of development of human capabilities. In Sen's concept of development, Gross Domestic Product (GDP) growth is seen as a means of expanding the fundamental freedoms enjoyed by members of the society. These freedoms depend on social and economic institutions (health and education) and on political and human rights (freedom of political participation). In addition, it starts out from the idea that institutions, besides defining the framework of action of human beings in the social sphere, can shape their behaviour, by changes in values. In this sense, social policy must be placed at the same level as economic policy to ensure a balanced and sustained development. Therefore the tax system is shaped as an institution fundamental to the definition of State capacity and of development policy, and as a key element of institutional quality, because it generates the resources to create institutions of a high standard, and contributes to the establishment of a closer relationship between the State and the citizen. The Political Economy of taxation provides a good interpretative framework for the creation of the State in undeveloped countries to propose a fiscal agenda for development. The paper is organized as follows. After a brief introduction, Section 2 addresses the mounting literature on State building. Section 3 studies the relationship between state capacity and development. Finally, Section 4 proposes a tax reform for development.
\end{abstract}

Keywords: taxation, development, state building, fiscal contract, capacities approach, State capacity

\section{INTRODUCTION}

The work of North and other neoinstitutionalists has had a significant impact, both in the academic world, in which it has produced advances in theory and method, and in development agencies, reorienting programs from market fundamentalism to the promotion of good governance (Bates 2010). In order to orientate "good governance" and "good policies" recommended to undeveloped countries, many indicators of institutional quality have been created, allied with quality of governance, the protection of property rights, respect for laws and contracts and the control of political leaders. (Edison 2003).

The critical literature downplays the advances, and ascribes the institutionalist enthusiasm of the academic world to the exhaustion of neoclassic theory (Nelson and Sampat 2001), and to the interest in masking the failures of the "good policies" supported theoretically in this line of thinking (Chang 2007). In practice, the influence of the New Institutional Economy (NIE) has resulted, according to its critics, in the rise of "institutional monoculture", that is, the universal implementation of a model of institutional architecture idealized from western experiences in developing countries, without regard to their historic, political and social context (Przeworski 
2004; Evans 2005 Mkandawire, 2009). The results have been very negative, it is argued, because the external imposition of institutional rules confutes institutional diversity and reduces the possibility for societies to construct their own constitutions (Rodrik 2008), and because it is based on a legal and ahistorical view of institutions (Toye 2007).

The neoinstitutionalists' concept of redistributive politics as a mere creation of unproductive revenue minimizes the role of the distribution of income and wealth in the persistence of dysfunctional institutions and in the failure of collective action (Bardhan 2001). Thus, in the social dimension (corruption and social capital), in the economic dimension (functioning of the markets and respect for private property) and the political dimension (political freedom and stability), which are included in the construction of indicators, the institutions that reduce the risks of conflict through redistributive measures and social protection are disregarded.

The influence of Public Choice on new institutional economics leads to the concept of excessive regulation and taxation as an assault on the rights of ownership, and taxation itself as a reflection of the coercive power of the State (Batley and Larbi 2004; Duff 2005). The model of the "Leviathan" State (Brennan and Buchanan 1980) maintains that the financial crises in undeveloped countries derives from wastefulness. However, the financial problem of these countries lies in the inability to collect taxes. This inability reflects its difficulty to establish political legitimacy and its institutional weakness in the administration and management of taxes (Toye 2000; Chang 2002).

Despite its positive effects on the legitimacy of institutions and good governance, in the generation of indicators of constitutional quality, the financial capacity of the State is sidelined. Thus, the Index of Economic Freedom associates institutional quality with the low incidence of the State's tax collection, with the result that the multilateral organizations recommend the establishment of neutral tax systems, which do not discourage private initiative or interfere with market signals, and limit social spending (Leroy 2010). The international organizations conceive tax reform as a "technical" problem, associated with administrative reform (World Bank 1991), but, according to research on the historical process of the formation of States, it is known that the inability of the State to build a unified and nondiscriminatory tax and legal system was the principal constraint on pre-modern economic growth (Bräutigam 2008a; Epstein 2009).

If taxation was a central element in the formation of the State, at present, the fiscal capacity should be understood as a prerequisite of the state capacity and of the strategies of development. In this sense, the recent financial crises suffered in various States of Sub Saharan Africa and Latin America have warned of the need to implement tax systems that increase the state's capacity to carry out developmental strategies (Keen 2012). Thus, a hidden facet of development is revealed: if the State does not have the institutional capacity to increase tax revenues, it cannot provide public services for development (Di John 2007, 2009).

On the other hand, the most recent neoinstitutionalist literature continues to reflect on the countries' economic performance, measured in terms of growth of production and income, and scarcely considers the concept of development, measured by the Human Development Index (HDI). It also affects the role of institutions as formal and informal rules, which make up the political, economic or social incentives of human interaction (North 1990). Similarly, it places too much emphasis on the creative institutions of the market and on the conditions of governance that strengthen it (Rodrik et al. 2004; Khan 2008). 
In this paper Sen's (1999) approach of capacities is adopted, emphasizing the constitutive role of institutions (Hodgson 2006), and it is assumed that the latter must perform the function of development of human capabilities (Chang 2011). This function may be realised with various institutional forms, adapted to the specific context and historical stage of each society (Roland 2004). In Sen's concept of development, Gross Domestic Product (GDP) growth is seen as a means of expanding the fundamental freedoms enjoyed by members of the society. These freedoms depend on social and economic institutions (health and education) and on political and human rights (freedom of political participation). In addition, it starts out from the idea that institutions, besides defining the framework of action of human beings in the social sphere, can shape their behaviour, by changes in values (Chang and Evans 2005; Chang 2007; Dutt 2011; López Castellano and García Quero, 2012).

Whilst the central elements of human development depend on per capita income, growth also depends on essential factors of human development such as health and education (PNUD 1990; Agosin et al 2005). In this sense, social policy must be placed at the same level as economic policy to ensure a balanced and sustained development (Mkandawire 2001; Block and Evans 2005). Therefore the tax system is shaped as an institution fundamental to the definition of State capacity and of development policy (Prichard 2010), and as a key element of institutional quality, because it generates the resources to create institutions of a high standard, and contributes to the establishment of a closer relationship between the State and the citizen (Gupta and Tareq 2008; Alonso and Garcimartín 2013).

The principal objective of this paper is to show that taxation is a crucial element of good governance and the legitimacy of the State and of the citizen's commitment with politics, and, finally, of development. Assuming that "social heritage" as regards education, health and collective contributions largely explains differences in income at an international level, we investigate the relationships between State and society in terms of taxation and we conclude with the importance of the tax system in the formation of the state and in the adoption of development strategies. The Political Economy of taxation provides a good interpretative framework for the creation of the State in undeveloped countries to propose a fiscal agenda for development. The paper is organized as follows. After a brief introduction, Section 2 addresses the mounting literature on State building. Section 3 studies the relationship between state capacity and development. Finally, Section 4 proposes a tax reform for development.

\section{RECENT LITERATURE ON TAXATION AND DEVELOPMENT: TAXATION AND STATE BUILDING}

Tax reforms for development during the last years of the twentieth century, supported by international organizations, favoured economic efficiency and collection, and ignored the redistributive impact of the tax system and its positive effects on the legitimacy of the State (Bird and Das-Gupta, 2012). The idea of "one size fits all" prevailed, and the tax systems of more advanced countries were reproduced, without consideration for the particularities of undeveloped countries, their institutional inadequacies, their problems of corruption and tax evasion (Das-Gupta and Mookherjee 1998; Bowles 1998), nor the socio-economic and political costs of capital flight (Boyce and Ndikumana 2005; Spencer 2006; Christensen 2009). The proposed tax reform was built around the implementation of a broad-based tax system, with lower rates for capital, corporations and individuals, with a value added tax on domestic consumption, and indirect taxes on specific consumption, and the removal of customs tariffs (Brauner and Stewart 2013).

With regard to State administration, until the 1980s, most undeveloped countries were encouraged towards Weberian-style public administration systems. Responding to pressure 
from the IMF, the World Bank and the influence of some donors, the New Public Administration was being adopted, which incorporated techniques from the private sector in the provision of basic services, inadequate for the building of developing States (Fjeldstad and Rakner, 2003).

Recently, studies are being revitalized on taxation and development due to the growing literature on state building (Bird 2012). Understanding state building as an endogenous process of capacity development, institutions and legitimacy of the State, the notion of the "Fiscal State", of Schumpeterian origin, narrates the process of institutionalization of representative government in Western Europe, emphasizing the role of the tax policy in this process. The model of the "Rentier State", of Buchanian origin, is becoming one of the main directions of research in development economy and relates the pathologies in the political Constitution of many countries to a high dependence on natural resources and foreign aid.

Neoinstitutionalism links the formation of the modern Nation-State and the economic development of Western Europe with the presence or absence of "good institutions". The narrative on the economic and political development of western societies begins at the moment when business and industry go beyond the boundaries of the feudal estate and the town, and the creators of this wealth recognize that the private costs of protection could be reduced if they are assumed by a collective authority. The issue is established in terms of "balance". According to this, the institutions are the result of negotiation between the authority and the population on the economic measures necessary for state activity. The type of State reflects the bargaining power of the monarch to exchange rights and privileges with representative bodies in return for revenue. Thus, the subjects will try to obtain the "constitutional" power to fix the price of protection (taxes), and the sovereign will try to obtain the monopoly of power in order to achieve greater income (North 1990, 2005; North and Weingast 1989).

The "Political Economy of Development", linked to the neoinstitutionalism of "Rational Choice", adopts this analytical approach and investigates the role of violence as a source of prosperity (welfare), depending on its public or private provision, and the influence of predatory governments on development (Olson 1993; Bates 2001). The idea takes the Schumpeterian concept of the State as a community of defence and finance, and the notion that the immediate cause of the creation of the modern State was financial necessity caused by growing military spending and its satisfaction through taxes (López Castellano and Lizárraga 2006).

The study of the shaping and evolution of the "Modern States" begins with the idea that wars between states and their preparation affected the formation of the State and its organizational structure. Military insecurity against the exterior and the need for public resources to finance defence favoured the creation of "liberal" political institutions. The state organizations treasuries, courts, administration, bureaucracies - emerged as by-products of the acquisition of resources to finance it (Tilly 1990; Blattman and Miguel 2010). To finance the wars, the Crown, monopolist of violence, and impelled by the imperative of income, was forced to extend the tax base from "real estate" to "goods", which made control more difficult and avoidance of payment easier. The cooperation of the owners of private assets was essential and this was achieved by creating institutional channels to reach agreements. In other words, the Crown opted for "seduction" rather than plunder in their dealings with the owners of wealth, and institutional channels arose in order to reach agreements. The economic imperative - the need for resources and the need to obtain them within the realm - became a political imperative and shaped the institutions of government. These parliamentary forms of government provided the incentives to encourage wealth, because power was used to guarantee to the owners of capital 
that the fruit of their investment and, with it, the increase in national wealth, would not be an object of plunder by the controllers of the instruments of coercion (Bates 2001).

Assuming the existence of differences, but also of similarities between seventeenth century England and many contemporary countries of the Third World, explains why the latter did not follow the patterns of development of the modern states. The reasoning is that modern underdevelopment is not due to economic policy, similar to the first European States, but to the differences of the international system which they encountered, which employed a use other than violence. That is, the two conditions were absent which had facilitated political order in favour of growth and which formed the modern States: the military imperative - their proclamation as sovereign nations reduced the possibilities of armed conflict - and the economic imperative - the abundant source of funding, which foreign aid implied, reduced the incentives to create wealth. This dual reason resulted in a different relationship between the political elite and the citizenry, it reduced the incentives to create "liberal" institutions, distanced them from democratic forms of politics and led them towards macroeconomic instability (Bates 2001).

More recently, and based on the narrative of the formation of the "modern" state, the political and legal institutions favouring development have been studied in depth, emphasizing the importance of the promotion of the market and the collection of taxes, and fiscal capacity has been analysed in terms of incentives and as a reflection of past investments in public services (Acemoglu 2005; Besley and Persson 2009, 2010, 2013).

The concept of the rentier state is recent and presents two main lines of interpretation; that relating to the "curse of natural resources"; and that concerning the institutional deterioration which causes high dependency on international aid (Moss et al. 2006; Gambaro et al. 2007). In both cases, this influential model of government maintains that funding through external sources (exploitation of mineral deposits, foreign aid) leads States into predatory behaviour. The reduced dependence on collection of domestic taxation makes the politicians less likely to be accountable to society, more prone to profit seeking and corruption and less capable of promoting policies that encourage growth.

The interpretation of the "curse of natural resources", linked to the theory of "Rational Choice", connects the abundance of natural resources with the possibility of violent conflict (Collier and Hoeffler 1998, 2004; Fearon and Laitin 2003). The State becomes a predatory instrument, and the indicator of state collapse is the militarization of civil society, because the citizens react to the predatory attitude of the governments by means of depoliticization or the private provision of security (Bates et al 2002).

The neoinstitutionalist account has been questioned because it assumes that all countries can build an institutional framework for growth, and that the same model of state building can be applied (Ottaway 2002). However, undeveloped states are not the result of a fiscal contract, rather that they were created through the mechanisms and relationships of direct colonial domination, indirect dependency, aid and the creation of international institutions. The Rational Choice approach, which maintains that governance and economic growth are the result of decisions taken by key actors who respond to material incentives has also been criticized (Cramer 2002). The hypothesis of the conflict theories, which explain violence as an economic rationality or rational political strategies, has also not been corroborated (Cramer 2006; Keen 2012), nor does it take into account the role of politics in the conflict, nor the fragility of the process of nation building (Chabal 2007). 
Recently, several authors point to the existence of processes of state building similar to those of the "modern" states (Brautigam 2008b; Gervasoni 2010), although with perceptions of external threats other than war, such as the action of domestic social movements, financial crises or globalization (Di John 2007; Thies 2007). Some authors propose adapting the historical European hypothesis of the existence of a virtuous circle between taxation and institutional building to the current undeveloped world (Moore 2008).

In whichever case, and as evidenced by history, state building requires the creation and the active use of the tax system to obtain income, to tax suitable sources, to implement more efficient tax administration, and to strengthen the relationship between the State and society in terms of taxation. All in all, the literature of State building leaves a number of questions relating to the importance of the perception of the contributor about the destination of their contribution; to the connection between the sacrifice of paying taxes and the enjoyment of public spending; and to the negative relationship between the dependency on foreign aid and the profits of natural resources and the development of taxation.

\section{INSTITUTIONAL CAPACITY AND DEVELOPMENT}

The historical literature and empirical studies are consistent with the idea that the formation of the State and the expansion of its fiscal capacity were related processes (Baskaran and Bigsten 2013). In more recent times, in all the successful examples of development the capacity of the State has proven to be a critical variable. In the case of the East Asian developing states, the construction of political capabilities required extensive public intervention, whose strength to encourage development was due to what Evans (2007) called "embedded autonomy", that is, the combination of a Weberian bureaucracy with the existence of strong structural links with other important groups of the civil society. The significant contribution of social policy to development must be joined to this strategy (Chang 2005). The creation of national markets in the East coincided with the creation and expansion of state institutions (Polanyi 2001), and the transition to the market economy requires as a precondition the existence of a strong and effective government (Shaoguang 2003).

However, current approaches to state building have inverted the causality and have focused on strategies of government, rather than affecting capacity. Whilst in the West the emergence of representative institutions responded to the expansion of the State in bureaucratic and fiscal terms, in many undeveloped countries they became democracies before consolidating the State (D'Arcy 2012), before building an organized administrative base of power. In the West, the institutionalization of the State followed a long and turbulent path (Chang 2002). Similarly, the process of the institutionalization of taxation was very arduous and required profound transformations in all areas, and, above all, in the ways of perceiving the public good and general utility, and the relationships between State, society and the market. The institution of taxation was inseparable from the creation of the necessary organizational structure, and favoured the birth and development of two closely linked concepts: Public Authority and Common Good.

State building in undeveloped countries has been subject to contradictory imperatives, because it requires high standards of "good government", which necessitates a strong State, at the same time that restructuring and economic deregulation programs are weakening it. Without regard to historical experience and the process of the formation of the State, the structural changes of the late twentieth century, undertaken at the request of international organizations, increased the difficulty of tax collection, the fragility of state regulatory functions, and decreased the capacity to manage resources and provide basic public services, negatively affecting its legitimacy; and influenced the reduction of state spending, particularly social spending 
(Clapham 2003). The policy of low direct taxes, the dismantling of tariffs and the "tragedy" of having to give tax incentives for foreign investment, has reduced their revenue capacity, impeding their ability to undertake policies of development, and has not contributed to State building (Tanzi and Zee 2001; De Mooj and Ederveen 2001; Keen and Simone 2004; Bird and Zolt 2005; Avi-Yonah 2006; Brauner 2013; Dagan 2013).

In order to define institutional quality and to construct institutional indicators, neoinstitutionalist literature identifies institutions that encourage growth with the way in which the participants interact in a market with low transaction costs and the kind of regulations and organizational structure that favours this interaction, and with the belief in capitalist values (Ruccio 2011). It also takes as reference the formal institutions whose effectivity largely depends on the support of informal institutions (norms, codes of conducts and cultural factors), of utmost importance in traditional societies. Finally, the strategy of institutional monocropping assumes the existence of a unique set of optimal institutions, it attributes the institutional change to political decisions and new laws (Easterly 2008), fosters a dangerous isomorphism (Andrews 2010), and ignores the costs of the institutional reforms (Chang 2011).

Sen's concept of development requires the construction of a new institutional framework, that favours the view that the distribution of wealth and the development strategy must be established through democratic processes. The notion of democracy is understood in the sense of "government through debate", because it generates values and the vote expresses a judgement on the most appropriate political choice to promote the common good. Evans (2005), Chang (2007) and Rodrik (2010) vindicate this notion of democracy and adopt Sen's agenda (2004) to create public debate on the distribution of collective goods and the strategy of development as a cornerstone of all proposed institutional change. As an alternative to institutional monocropping it is proposed to urge deliberation, experimentation and institutional innovation in the developing countries themselves (Evans 2004).

The capacity approach places at the core of the analysis the determination of the institutional mechanisms necessary to foster public debate, that is to say, the institutions that enable collective decisions on the aims of development. This participatory strategy requires the involvement of the population in the discussion on the rules, the objectives of development, and the measures necessary to achieve them (Portes 2007). In order to accomplish these deliberative forms of economic government that allow the people to choose the type of life that they value, Evans (2005) establishes two paths: to level the cultural field, diversifying the sources of information which the citizen receives, and to create the collective capacity to expand the individual's capacity, investing in the expansion of opportunities for public discussion and interaction.

On the other hand, the States that are successful in their strategies of development have generated governmental capacities and built state-societal relationships that are mutually supportive. The developmentalist capacities of the State depend on the political capacity and the capacity to mobilize resources, that is, the proficiency of the States to generate resources to distribute quality services and protection to wide sectors of the population. The mobilization of domestic resources, therefore, is key to achieving these objectives, because it strengthens the links with citizens and increases the political space. In this sense, it is about advancing from market making institutions to institutions for development, which means strengthening the capacity of the State to acquire the resources for fostering equality of opportunities. Taxation and social security are established in institutions crucial to development, because they create 
synergies between economic and social development, they improve the distribution of income and assets in society and strengthen democracy and solidarity within states.

Thus tax reform in order to guarantee domestic resources becomes the principal financial strategy for development, because tax is superior to foreign aid or other sources of finance. It has been shown that dependency on aid or the income derived from natural resources discourages institutionalized political activity, does not promote accountability, and inhibits State capacity (Moore 2004, 2008; Cornia et al. 2011; OECD 2012; CEPAL 2012), discourages governments from taxation, and leads to a deterioration in the quality of government institutions (Rajan and Subramanian 2007).

\section{REFLECTION AND PROPOSAL: A TAX SYSTEM FOR DEVELOPMENT}

As we have seen, taxes play a key role in the capacity of the State and are an objective indicator of its power and legitimacy to promote development (Bräutigam 2008a; Keen and Lockwood 2010). The relative backwardness in developing countries can be explained by the limitations to obtain the necessary resources to provide public services such as health, education and infrastructure that promote economic growth, and to implement social programs and transfers with redistributive objectives (BID 2012). The tax system determines the potential of the public sector to provide goods and services and to carry out redistributive programs. Progressive tax is the crucial element for creating a solid, democratic State legitimized by its citizens, especially in environments of elevated inequality. Economic inequality increases the incentives of the economic elite to act as "fiscal termites" (Elizondo and Santiso 2008) and to obtain benefits from public policies (Alesina and Perroti 1996; Esteban and Ray 1999; Gómez Sabaini and Martner 2008).

However, a series of characteristics are rooted in the tax structures of developing countries which hinder the advancement of development policies: low tax collection, low progressiveness, high tax evasion, administrative weakness, low tax morale and bad governmental management (Attila et al. 2008). Therefore, tax reform for development should focus on the increase of progressivity of the tax system with a tax on income of high redistributive capacity; on the simplification of rules and the expansion of the taxable bases, incorporating untaxed or inadequately taxed activities; on the strengthening of tax administrations and the establishment of a "compliance technology" which guarantees the application of the rules; and on the fostering of a culture of contribution that increases tax "morale" and favours this compliance (Fjeldstad et al. 2012; BID 2013).

In order to achieve this, a fiscal pact needs to be established, that is, a political agreement, explicit or implicit, of the political and social participants on the origin, destination and composition of the resources necessary to finance the State. The other basic pillar of the system must be to increase the "tax morale", that is to say, the belief in contribution to society through the payment of taxes.

\section{Towards a social fiscal pact}

In the orthodox theory of the State there is always a latent fundamental political dilemma: as a monopolist of violence, the State creates the rules of play, but its power can also permit it to violate them (Weingast 1995). The State fulfils the crucial function of ensuring property rights and guaranteeing the fulfilment of contracts, to reduce transaction costs, increase wealth and encourage growth, but mechanisms of collective action must be designed to limit its predatory capacity and discourage its opportunistic behaviour (Shirley 2008). The reductionist vision of the State as a "revenue-maximizing Leviathan", is emphasized in the analysis of undeveloped countries (Toye 1987). 
The orthodox image of the State conceals the view of egoism as a theory of motivation and human behaviour, and the rejection of the "public" nature of the motivations of politicians and state bureaucrats. Methodological individualism discards the public interest as a category and reduces social and collective phenomena to theories on individual human action. Political objectives are measured in terms of individual utility, and the criteria of Pareto is invoked to establish normative propositions (Rutherford 2001; Reinert 2007). The utilitarian arguments on corruption evoke Mandeville, because it is seen as oil on the gears of economic activity, without allowing for its social costs, and without taking into account the existence of irreducible values and commitments to questions of incentives (Hodgson 2007).

As opposed to the view of the Leviathan tax State, this paper assumes the notion of the contractual State and the constitutive role of institutions is emphasized. On the one hand, institutions are not only a set of restrictions within which individual politicians and bureaucrats maximise their utility rationally, but rather that they confer legitimacy, authority and power to those that participate in them. On the other hand, higher ethical values may exist which can be successfully invoked, such as justice, public spirit, altruism, or good will (Steinmo and Lewis 2011), and individuals who think "institutionally", that is, who are aware of their own duty beyond personal or organizational loyalty (Heclo 2008), and when integrated into public life, they culminate in internalizing "publically oriented" values. In all cases, both the behaviour and the motivations of public figures can be modified through ideological exhortation, directly, by emphasizing the public service ethic in the process of bureaucratic training; or indirectly, by changing the institutions that encompass them (Chang 2007).

In order to achieve a certain level of social consensus and legitimacy of government, it is necessary to stimulate public debate and exercise democratic persuasion (Schneider et al. 2004). Tax collection is based on a tacit agreement between society and the State and is a central part of the relationship between them. The fiscal policy can be considered as a contract between citizens, and between citizens and governments, founded on the interaction of socioeconomic, politico-institutional and cultural variables, in which legitimacy plays an important role. The level of social consensus and legitimacy of government are two closely related factors with the state capacity to determine tax policy and avoid the blocking of stakeholders.

The social fiscal pact is the manifestation of the social contract resulting from the mutual recognition of obligations and rights between State and citizens (CEPAL 1998). Through this pact, citizens are linked to a contractual State, agreeing to assume certain financial obligations in exchange for a set of benefits and public services. A better public management will lead to a greater willingness to pay taxes, and a better payment of taxes is reflected in a greater participation of the citizenry in the control of the government, that is, in a greater "voice" and political responsibility (Persson and Tabellini 2004; Bird et al. 2008; CAF 2012).

The fiscal contract, based on the exchange of taxation for representation and citizenship, and public services, depends on the confidence of the citizens in the public administration and on their perception of justice, the transparency and reciprocity of the taxation and of the destination of public revenue. If the citizens' confidence in the State's management of taxes is very low, the fiscal pact is weakened. The fiscal pact also depends on the functioning of the tax system and the agencies or institutions of the state apparatus responsible for the execution of public spending. In order to encourage confidence between State and citizens, the tax administration and its sanctioning capacity must be strengthened, to promote horizontal equity and to avoid the exclusion of the law. 


\section{Social fiscal pact and citizenship}

The classic model of public finance emphasizes the coercive aspects of tax collection without considering the non-economic aspects of the behaviour of the citizen. Tax compliance is identified with the individual decision between paying and evading taxes, without considering the implicit or "psychological" contract, or the ethical aspects of the interrelationship between contributors and authorities. The study of tax compliance from a social and moral dimension is still underdeveloped (Erard and Feinstein 1994; Andreoni et al. 1998), and studies on the influence of institutions on morale and tax compliance are scant (Prinz 2010). Studying tax morale is crucial, because it can help to explain the level of tax compliance or evasion (Torgler 2002; Bird and Das-Gupta 2012).

The thesis that there is a nexus between tax structure and good governance starts from two hypotheses: of reciprocity and of empowerment. On the one hand, the citizens will have a greater willingness to pay taxes if their perception of the quality of government is good; on the other hand, when the citizens contribute more to the treasury, incentives are generated to participate in the control of the authorities, which results in a better quality of management. Citizenship is a concept complimentary to the social contract in which a citizen expresses the relationship between the individual and the State in a contractual sense of rights and obligations (Waris and Kohonen 2009).

The voluntary nature of tax compliance reflects a behaviour of "good" citizenship. However, institutional quality and the citizens' confidence in the functioning of institutions influences the tax morale and the level of voluntary compliance (Fjeldstad 2008; Keen and Mansour 2010). The Treasury should not ignore institutions such as civic culture or social capital (Coleman 1990; Putnam et al. 1993), of particular importance in developing countries, where informal institutions substitute or complement formal institutions. (Knack and Zak 2001; Durlauf and Fafchamps 2005). The beliefs and traditions of members of society shape the attitudes of individuals towards the decisions of public tax policy and determine the tax capacity of the government. Social consensus and the legitimacy of the government are built on the foundations of the beliefs of individuals, their perceptions of state action, and tax compliance depends on the citizens' perception of taxation, of its tax "culture" (McGee 2008). Citizens understand that they must pay taxes if they are to be translated into public benefits and services. Therefore the credibility of the policies, the way in which the government spends public resources, will determine their level of legitimacy and their right to demand more revenue from the contributors (Knack and Keefer 1997).

Weck (1983) empirically demonstrated that there is a negative correlation between tax morale and the size of the submerged economy, Gordon and Li (2009) emphasized the size of the informal sector, and Torgler (2002) found that tax morale significantly reduces tax evasion. Tax morale, that is, the perception of the payment of taxes as a civic duty and the rejection of evasion, is linked to the view of the citizenry on the role of the State, and of the behaviour of other citizens (Frey and Torgler 2007; Frey and Meier 2004; Brautigam 2008a, 2002).

In short, this paper has explored the literature on taxation and development, especially the narrative on the formation of states and the recent proposals of tax reform recommended by international institutions for undeveloped countries.

Some basic ideas merit repetition here. Although the literature endorses the concept that taxation and tax reform are fundamental elements for the creation of states, fiscal capacity is not included in the indicators of institutional quality and in the proposals of tax reform. Neither is it ultimately explained that the failure of the fiscal policy can reflect imbalances 
between the proposals of tax reform and the culture and the social and political context of its application.

This paper argues that the mobilization of domestic revenue contributes to the strengthening of fiscal institutions and that social policy has a strong, positive correlation with the quality of these institutions. Undeveloped countries should increase their capacity, through the creation of a stable and predictable tax system that promotes growth and reduces the dependence on development aid. Fiscal reform should contribute to the construction of the State through the acquisition of income from appropriate sources; the creation of more efficient tax administration; and the fostering of the relationship between State and society in terms of taxes.

Finally, as opposed to the growth approach, which emphasizes the Gross Domestic Product (GDP), the capacities approach permits an understanding that the tax system is the key institution of state capacity and that, together with social policy, it serves the function of increasing the citizens' liberties of decision and action, and of promoting human development.

\section{References}

Acemoglu, Daron. "Politics and Economics in Weak and Strong States." Journal of Monetary Economics 52 (2005): 1199-1226.

Agosin, Manuel R., Alberto Barreix and Roberto Machado. Recaudar para crecer: bases para la reforma tributaria en Centroamérica. Washington: Banco Interamericano de Desarrollo (BID), 2005.

Alesina, Alberto, and Ricardo Perotti. "Income Distribution, Political Instability, and Investment." European Economic Review 40, 6 (1996): 1203-1228.

Alonso, J. Antonio, and Carlos Garcimartín. "The determinants of institutional quality. more on the debate." Journal of International Development 25, 2 (2013): 206-226.

Andreoni, James, Brian Erard and Jonathan Feinstein. "Tax Compliance." Journal of Economic Literature 36, 2 (1998): 818-860.

Attila, Gbewuopo, Gérard Chambas and Jean-Louis Combes. Aide publique au développement et transition fiscale. Etudes et Documents du CERDI E2008.16.

Avi-Yonah, Reuven. "The Three Goals of Taxation." Tax Law Review 60, 1 (2006): 1-28.

Bardhan, Pierre. "Deliberative Conflicts, Collective Action and Institutional Economics." In Frontiers of Development Economics: the Future in Perspective, edited by G. Meier and J. Stiglitz , pp. 269-290. New York: Oxford University Press, 2001.

Baskaran, Thushyanthan, and Arne Bigsten. "Fiscal Capacity and the Quality of Government in Sub-Saharan Africa." World Development 45 (2013): 92-107.

Bates, Robert. "The New Institutionalism." Prepared for the conference on "The Legacy and Work of Douglass North: Understanding Institutions and Development Economics”, Center for New Institutional Social sciences. Washington University, St. Louis, 2010.

Bates, Robert. Prosperity and violence: the political economy of development. New York: Norton, 2001.

Bates, Robert, Avner Greif and Smita Singh. "Organizing Violence", Journal of Conflict Resolution 46, 5 (2002): 599 628.

Batley, Richard, and George A. Larbi. The Changing Role of Government: The Reform of Public Services in Developing Countries. London: Palgrave Macmillan, 2004.

Besley, Timothy, and Torsten Persson. Taxation and development. Centre for Economic Policy Research, 2013.

Besley, Timothy, and Torsten Persson. "State Capacity, Conflict, and Development." Econometrica 78, 1 (2010): 134.

Besley, Timothy, and Torsten Persson. "The Origins of State Capacity: Property Rights, Taxation and Politics." American Economic Review 99, 4 (2009): 1218-44. 
Banco Interamericano de Desarrollo (BID) Recaudar no basta. Los impuestos como instrumento de desarrollo. Washington, D.C.: BID, 2012.

Bird, Richard. "Taxation and Development: What Have We Learned from Fifty Years of Research?." International Center for Public Policy, Working Paper 12-02, 2012.

Bird, Richard, and Eric M. Zolt. "Redistribution via Taxation; The Limited Role of the Personal Income Tax in Developing Countries". In International Tax Program Paper 0508. Toronto: Joseph L. Rotman School of Management, 2005.

Bird, Richard, Jorge Martínez-Vázquez and Benno Torgler. "Tax Effort in Developing Countries and High-Income Countries: The Impact of Corruption, Voice and Accountability." Economic Analysis and Policy 38, 1 (2008): 55-71.

Blattman, Christopher, and Edward Miguel. "Civil War." Journal of Economic Literature 48, 1 (2010): 3-57.

Block, Fred, and Peter Evans "The state and the economy." In Handbook of Economic Sociology, edited by N. Smelser and R. Swedberg, pp. 505-526. N. York: Princeton University Press, 2005.

Bowles, Robert. "Minimizing Corruption in Tax Affairs." In Further Issues in Tax Reform, edited by C.Sanford, pp. Bath: Fiscal Publications, 1998.

Boyce, James, and Léonce Ndikumana. "Africa's debt: Who owes whom?." In Capital Flight and Capital Controls in Developing Countries, edited by G.Epstein, pp. 334-340. Edward Elgar Press, 2005.

Brauner, Yariv, and Miranda Stewart. "Introduction." In Tax, Law and Development, edited by Y. Brauner, and M. Stewart, pp. 3-22. Cheltenham, UK: Edward Elgar, 2013.

Brauner, Yariv. "The Future of Tax Incentives for Developing Countries." In Tax, Law and Development, edited by Y. Brauner, and M. Stewart, pp. 25-56. Edward Elgar: Cheltenham, UK, 2013.

Brautigam, Deborah. "Introduction: Taxation and State Building in Developing Countries." In Taxation and State Building in Developing Countries: capacity and consent, edited by D. Brautigam, O-H. Fjeldstad and M. Moore. Cambridge: Cambridge University Press, UK, 2008a.

Bräutigam, Deborah. "Taxation and Governance in Africa: Take a Second Look." Development Policy Outlock 1 (2008b): 1-6.

Bräutigam, Deborah. "Building Leviathan: Revenue, State Capacity and Governance." IDS Bulletin 33, 3 (2002): 1020.

Brennan, Geoffrey, and James Buchanan. The power to tax: analytical foundations of a fiscal constitution. New York: Cambridge University Press, 1980.

Banco de Desarrollo de América Latina (CAF). Finanzas públicas para el desarrollo. Fortaleciendo la conexión entre ingresos y gastos. Reporte de Economía y Desarrollo. Bogotá: Corporación Andina de Fomento, 2012.

CEPAL. El Pacto Fiscal: Fortalezas, Debilidades, Desafíos. Santiago de Chile: ONU/CEPAL, 1998.

CEPAL. Reforma fiscal en América Latina: ¿qué fiscalidad para qué desarrollo?. Santiago de Chile: Cibob, 2012.

Chabal, Patrick. "Las políticas de violencia y conflicto en el África contemporánea." Revista Académica de Relaciones Internacionales, 6 (2007): 1-17.

Chang, Ha-Joon. "Institutions and Economic Development: Theory, Policy and History." Journal of Institutional Economics 7, 4 (2011): 473-498.

Chang, Ha-Joon. "Understanding the Relationship between Institutions and Economic Development. Some Key Theoretical Issues." In Institutional Change and Economic Development, edited by H.-J. Chang, pp. 17-33. London: Anthem Press, 2007.

Chang, Ha-Joon. "Globalization, Global Standards and the Future of East Asia." Global Economic Review 34, 4 (2005): 363-378.

Chang, Ha-Joon. "The role of Social Policy in Economic Development: some Theoretical Reflections and Lessons from Earsten Asian." In Social Policy in a Development, edited by T. Mkandawire, pp. New York: Palgrave Macmillan, 2004

Chang, Ha-Joon. Kicking Away. The Ladder Development Strategy in Historical Perspective. London: Anthem Press, 2002.

Chang, Ha-Joon, and Peter Evans. "The Role of Institutions in Economic Change." In Reimagining Growth, edited by G.Dymski and S. Da Paula, pp. London: Zed Press, 2005. 
Clapham, Christopher. "The Challenge to the State in a Globalized World." In State Failure, Collapse and Reconstruction, edited by J. Milliken, pp.25-44. London: Blackwell, 2003.

Coleman, James. Foundations of Social Theory. Cambridge, Mass: Harvard University Press, 1990.

Collier, Paul, and Anke Hoeffer. "Greed and Grievance in Civil War." Oxford Economic Papers 56, 4 (2004): 563595.

Cornia, Giovanni, Juan Carlos Gómez Sabaini and Bruno Martorano. "A New Fiscal Pact, Tax Policy Changes and Income Inequality. Latin America during the last decade." UNU-WIDER, Working Paper, № 2011/70, 2011.

Christensen, John. The long and winding road: tackling capital flight and tax evasion. Amsterdam: Transnational institute, 2007.

Cramer, Christopher. Civil War Is Not a Stupid Thing. Accounting for Violence in Developing Countries. London: Hurst \& Company, 2006.

Cramer, Christopher. "Homo Economicus Goes to War: Methodological Individualism, Rational Choice and the Political Economy of War." World Development 30, 11 (2002): 1845-1864.

D’arcy, Michelle. "Taxation, democracy and state-building: how does sequencing matter?." Working paper series 2012:4, University of Gothenburg, 2012.

Dagan, Tsilly. "The Tragic Choices of Tax Policy in a Globalized Economy." In Tax, Law and Development, edited by Y. Brauner and M. Stewart, pp. 57-76. Cheltenham, UK: Edward Elgar, 2013.

Das-Gupta, Anirvan and Dilip Mookherjee. Incentive and Institutional Reform in Tax Enforcement: An Analysis of Developing Country Experience. Oxford: Oxford University Press, 1998.

De Mooj, Ruud, and S. Ederveen "Taxation and Foreign Direct Investment: A Synthesis of Empirical Research." $C P B$ Discussion Paper No. 003, 2001.

Di John, Jonathan. Taxation as State-Building: Reforming Tax Systems for Political Stability and Sustainable Economic Growth: A Practioner's Guide. Washington, DC: Financial and Investment Climate Service (FIAS) / World Bank/DFID, 2009.

Di John, Jonathan. "The Political Economy of Taxation and Tax Reform in Developing Countries." In Institutional Change and Economic Development, edited by H.-J., Chang, pp. 135-155. London: Anthem Press, 2007.

Dincecco, Mark, and Mauricio Prado. "Warfare, fiscal Capacity and economic performance." Journal of Economic Growth 17 (2012): 171-203.

Duff, David G. "Private Property and Tax Policy in a Libertarian World: A Critical Review." Canadian Journal of Law and Jurisprudence 18, 1 (2005): 23-45.

Durlauf, Steven, and Marcel Fafchamps. "Social Capital." In Handbook of Economic Growth, edited by P.Aghion and S. N. Durlauf, pp.1639-1699. London: Elsevier, 2005.

Dutt, Amitava K. "Institutional Change and Economic Development: Concepts, Theory and Political Economy." Journal of Institutional Economics 7, 4 (2011): 529-534.

Easterly, William. "Institutions: Top Down or Bottom up?." American Economic Review: Papers \& Proceedings 98,2 (2008): 95-99.

Edison, Hali. "¿Vínculos sólidos? ¿Cómo es la relación entre la calidad institucional y el desempeño económico." Finanzas \& Desarrollo 40, 2 (2003): 35-37.

Epstein, Stephen. Freedom and growth: the rise of states and markets in Europe, 1300-1750. New York: Routledge, 2009.

Elizondo, Carlos, and Javier Santiso. "Devórame otra vez: termitas locales y violencia fiscal en América Latina; pactos sociales y pactos fiscales: México y Brasil desde una perspectiva comparada." En Hacia un nuevo pacto social: políticas económicas para un desarrollo integral en América Latina-LC/L. 2855-2008-p. 181-231 (2008).

Erard, Brian, and Jonathan Feinstein. "The Role of Moral Sentiments and Audit Perceptions in Tax Compliance." Public Finance 49 (1994): 70-89.

Esteban, Joan, and Debraj Ray. "Conflict and Distribution." Journal of Economic Theory 87, 2 (1999): $379-415$.

Evans, Peter. "Extending the institutional turn: property, politics, and development trajectories." In Institutional Change and Economic Development, edited by H.-J. Chang, pp. 35-52. London: Anthem Press, 2007. 
Evans, Peter. "The Challenges of the "Institutional Turn": New Interdisciplinary Opportunities in Development Theory." In The Economic Sociology of Capitalism, edited by V. Nee and R. Swedberg, pp. 90-116. Princeton: Princeton University Press, 2005.

Evans, Peter. "Development as Institutional Change: The Pitfalls of Monocropping and Potentials of Deliberation." Studies in Comparative International Development 38, 4 2004: 30-52.

Everest-Phillips, Max. "State Building Taxation for Developing Countries: Principles for Reform." Development Policy Review 28, 1 (2010): 75-96.

Fearon, James, and David Laitin. "Ethnicity, Insurgency and Civil War." American Political Science Review 97, 1 (2003): 75-90.

Fjeldstad, Odd-Helge. "Taxation and development. A review of donor support to strengthen tax systems in developing countries." WIDER Working Paper No. 2013/010, 2013.

Fjeldstad Odd-Helge, Ali Merima and Ingrid Sjursen. "To pay or not to pay? Citizens' attitudes towards taxation in Kenya, Tanzania, Uganda and South Africa." Afrobarometer Working Paper WB 143, 2012.

Fjelstad, Odd-Helge, and Mick Moore. "Revenue authorities and public authority in sub-Saharan Africa." Journal of Modern African Studies 47, 1 (2009): 1-18.

Fjeldstad Odd-Helge, and Bertil Tungodden. "Fiscal Corruption: A Vice or a Virtue?." World Development 31 (2003): 1459-1467.

Fjeldstad, Odd-Helge, and Lise Rakner."Taxation and tax reforms in developing countries: Illustrations from subSaharan Africa." Bergen: Chr. Michelsen Institute (CMI Report R 2003:6.

Frey, Bruno, and Stephan Meier. "Social comparisons and pro-social behavior: Testing 'Conditional Cooperation' in a field experiment." The American Economic Review 94, 5 (2004): 1717-1722.

Frey, Bruno, and Benno Torgler. "Tax morale and conditional cooperation." Journal of Comparative Economics 35, 1 (2007): 136-159.

Gambaro, Ludovica, Jonna Meyer-Spasche, and Ashikur Rahman. Does aid decrease tax revenue in developing countries? . London: London School of Economics, 2007.

Gómez Sabaini, Juan Carlos, and Robert Martner. América Latina: Panorama global de su sistema tributario y principales temas de política. Santiago de Chile: ILPES-CEPAL, 2008.

Gupta, Sanjeev, and Shamsuddin Tareq. "Mobilizing Revenue." Finance \& Development 45, 3 (2008): 44-47.

Heclo, Hugh. On Thinking Institutionally . Boulder: Paradigm Publishers, 2008.

Herb, Michael. "No representation without taxation? Rents, development, and democracy." Comparative Politics 37, 3 (2005): 297-317.

Hodgson, Geoffrey. "What are Institutions?." Journal of Economic Issues 40, 1 (2006): 1-25.

Hodgson, Geoffrey, and Shuxia Jiang. "The Economics of Corruption and the Corruption of Economics: An Institutionalist Perspective." Journal of Economic Issues, 41, 4 (2007): 1043-1062.

Khan, Mushtaq. "Governance and development: the perspective of growth-enhancing governance." GRIPS Development Forum/National Graduate Institute for Policy Studies, 2008.

Keen, Michael. "Taxation and Development-Again." IMF Working Paper, WP/12/220, 2012.

Keen, David. "Greed and grievance in civil war." International Affairs 88, 4 (2012): 757-777.

Keen, Michael, and Alejandro Simone. "Tax Policy in Developing Countries: Some Lessons from the 1990s and Some Challenges Ahead." In Helping Countries Develop: The Role of Fiscal Policy, edited by S. Gupta, B. Clements, \& G. Inchauste, pp. 302-52. Washington: International Monetary Fund, 2004.

Keen, Michael, and Ben Lockwood. "The Value Added Tax: Its Causes and Consequences." Journal of Development Economics 92 (2010): 138-51.

Keen, Michael, and Mario Mansour. "Revenue Mobilization in sub-Saharan Africa: Challenges from Globalization I Trade Reform." Development Policy Review 28 (2010): 553-71.

Knack, Stephen, and Philip Keefer. "Does Social Capital Have an Economic Payoff? A Cross-Country Investigation." Quarterly Journal of Economics 112, 4 (1997): 1251-1288.

Knack, Stephen, and Paul J. Zak. "Trust and growth." The Economic Journal 111, 470 (2001): 295-321. 
Leroy, Marc. L'impôt, l'etat et la société. Paris: Economica, 2010.

Lewis, Orion, and Sven Steinmo. "Tomemos en serio la evolución: análisis institucional y teoría evolutiva." Revista de Economía Institucional 13, 24 (2011): 111-151.

Lledo, Victor, Aaron Schneider, and Mick Moore. "Social Contracts." Fiscal Pacts and Tax Reform in Latin America, Washington, DC, Banco Interamericano de Desarrollo (BID), 2004.

López Castellano, Fernando, and Fernando García Quero. "Institutional Approaches to Economic Development: The Current Status of the Debate." Journal of Economics Issues 46, 4 (2012): 921-940.

López Castellano, Fernando, and Carmen Lizárraga. "Violencia, instituciones y prosperidad: critica a la economía política del desarrollo". Problemas del Desarrollo 37, 145 (2006): 203-213.

McGee, Robert. "Three views on the ethics of tax evasion." Journal of Business Ethics 67, 1 (2006): 15-35.

Mkandawire, Thandika. Institutional Monocropping and Monotasking in Africa. Oxford University Press, 2009.

Mkandawire, Thandika. Social Policy in a Development Context, Jenova: United Nations Research Institute for Social Development, 2001.

Moore, Mick. "Between coercion and contract: competing narratives on taxation and governance." In Taxation and State-Building in Developing Countries, edited by D. Bräutigam, 0. H. Fjeldstad and M. Moore, pp.34-63. Cambridge: Cambridge University Press, 2008.

Moore, Mick. "Revenues, State Formation, and the Quality of Governance in Developing Countries." International Political Science Review 25, 3 (2004): 297-319.

Moss, Todd, Gunilla Pettersson, and Nicolas Van de Walle. An aid-institutions paradox? A review essay on aid dependency and state building in sub-Saharan Africa. No. 74. 2006.

Nelson, Richard, and Bhaven N. Sampat. "Making sense of institutions as a factor shaping economic performance." Journal of Economic Behavior \& Organization 44.1 (2001): 31-54.

North, Douglass C. Institutions, Institutional change and Economic Performance . New York: Cambridge University Press, 1990.

North, Douglass C. Understanding the Process of Economic Change. Princeton: Princeton University Press, 2005.

North, Douglass C., and Barry Weingast. "Constitutions and Commitment: The Evolution of Institutions Governing Public Choice in Seventeenth century England." The Journal of Economic History 49, 4 (1989): 803-832.

OECD. "Taxation, State Building and Aid." Factsheet, Updated December 2009, Paris. Available at www.oecd.org/dac/governance.

Olson, Mancur. "Dictatorship, Democracy and Development." American Political Science Review 87, 3 (1993): 566576.

Ottaway, Marina. "Rebuilding state institutions in collapsed states." Development and change 33, 5 (2002): 10011023.

Persson, Torsten, and Guido Tabellini. "Constitutional rules and fiscal policy outcomes." American Economic Review 94 (2004): 25-45.

PNUD Informe sobre el Desarrollo Humano. Bogotá: Tercer Mundo editores, 1990.

Polanyi, Karl. The Great Transformation: The Political and Economic Origins of Our Time. Boston: Beacon Press, 2001.

Portes, Alejandro. "Instituciones y desarrollo: una revisión conceptual." Desarrollo Económico 46, 184 (2007): 475-503.

Prichard, Wilson. "Taxation and state building: Towards a governance focused tax reform agenda." IDS Working Papers 2010.341 (2010): 01-55.

Prinz, Aloys. "A moral theory of tax Evasion." Unpublished Manuscript, Westfälische Wilhelms-Universität Münster, 2002.

Putnam, Robert, Robert Leonardi, and Raffaella Y. Nanetti. Making democracy work: Civic traditions in modern Italy. Princeton university press, 1994.

Przeworski, Adam. "The Last Instance: Are Institutions the Primary Cause of Growth?." European Journal of Sociology 45, 2 (2004):165-188. 
Rajan, Raghuram, and Arvind Subramanian. "Does Aid Affect Governance?." The American Economic Review 97, 2 (2007): 322-327.

Reinert, Erik S. How rich countries got rich and why poor countries stay poor. London: Constable, 2007.

Rodrik, Dani. "Diagnostics before Prescription." Journal of Economic Perspectives 24, 3 (2010): 33-44.

Rodrik, Dani. "Second-Best Institutions." American Economic Review: Papers \& Proceedings 98, 2 (2008):100-104.

Rodrik, Dani, Arvind Subramanian, and Francesco Trebbi, F. "Institutions Rule: The Primacy of Institutions over Geography and Integration in Economic Development." Journal of Economic Growth 9, 2 (2004): 131-165.

Roland, Gerard. "Understanding Institutional Change: Fast-moving and Slow-moving Institutions." Studies in Comparative International Development 38, 4 (2004): 109-131.

Ross, Michael L. "The political Economy of the Resource Curse." World Politics 51, 2 (1999): 297-322.

Ruccio, David F. "Development, Institutions and Class." Journal of Institutional Economics 7, 4 (2011): 571-576.

Rutherford, Malcolm. "Institutional Economics: Then and Now." Journal of Economic Perspectives 15, 3 (2001): 173-194.

Sen, Amartya. "Elements of a Theory of Human Rights." Philosophy \& Public Affairs 32, 4 (2004): 315:356.

Sen, Amartya. Development as Freedom. New York: Alfred Knopf, 1999.

Shaoguang, Wang. "The State, Market Economy, and Transition." Asian Exchange 19, 3 (2003): 224-244.

Shirley, Mary. Institutions and Development. Cheltenham and Brookfield. VT: Edward Elgar, 2008.

Spencer, D. "The IMF and Capital Flight: Redesigning the International Financial Architecture." The Tax Justice Network (www. brettonwoodsproject. org/atissuecapitalflight) (2006).

Thies, Cameron. G. "The Political Economy of State Building in sub-Saharan Africa." Journal of Politics 60 (2007): 716-731.

Tilly, Charles. Coercion, Capital and European States: Ad 990 - 1992. Oxford: Wiley-Blackwell, 1990.

Torgler, Benno. Tax morale and institutions. Wirtschaftswissenschaftliches Zentrum (WWZ) der Universität Basel, 2002.

Torgler, Benno, and Cristoph A. Schaltegger. "Tax Amnesties and Political Participation." Public Finance Review 33, 3 (2005): 403-431.

Torgler, Benno, and Friedrich Schneider. "The Impact of Tax Morale and Institutional Quality on the Shadow Economy." Journal of Economic Psychology 30, 2 (2009): 228-245.

Toye, John. "Prospects for a Theory of Institutions and Development." In Glasgow University"s International Conference on Development Economics, June 26-7-2007.

Toye, John. "Fiscal Crisis and Fiscal reform in developing countries." Cambridge Journal of Economics 24, 1 (2000): 21-44.

Toye, John. Dilemmas of development: reflections on the counter-revolution in development theory and policy. Oxford: Blackwell, 1987.

Waris, Attiya, and Matti Kohonen. Taxation and State building in Kenya: Enhancing revenue capacity to advance human welfare. Tax Justice Network Africa, 2009.

Wasylenko, Michael. "Taxation and Economic Development: The State of the Economic Literature." New England Economic Review March/April (1997): 38-52.

Weingast, Barry. "The economic Role of Political Institutions." The Journal of Law, Economics and Organization 1, 1 (1995): 1-31.

World Bank Lessons of Tax Reform. Washington, DC: The World Bank, 1991. 